\title{
Damages Arising from Contraventions of Competition Act 89 of 1998
}

M Ratz*

\section{P.E.R}

Pioneer in peer-reviewed, open access online law publications

Author

Malcom Ratz

Affiliation

Partner at Kruse Attorneys

Incorporated, Pretoria, South Africa

Email malcolm@rkattorneys.co.za

Date Submission

26 October 2016

Date Revised

15 May 2019

Date Accepted

15 May 2019

Date published

13 June 2019

\section{Editor Prof C Rautenbach}

How to cite this article

Ratz M "Damages Arising from

Contraventions of Competition Act 89 of 1998" PER / PELJ 2019(22) DOI

http://dx.doi.org/10.17159/1727-

3781/2019/v22i0a1529

Copyright

DOI

http://dx.doi.org/10.17159/1727-

3781/2019/v22i0a1529

\begin{abstract}
Persons who have suffered loss or damage as a result of a prohibited practice in terms of the Competition Act 89 of 1998 (the Act) have the right to recover such damage in the civil courts. This right is expressly provided for in section 65 of the Act. To date South Africa has failed to usher in an efficient and effective environment for section 65 civil damages actions, despite growing success being achieved by the competition authorities in uncovering and prosecuting firms for contraventions of the Act, including prohibited practices. Understanding how section 65 rights might be vindicated and whether South Africa's damages regime is adequate to deal with potentially complex damages actions within the realm of competition law contraventions, a starting point would be to gain certainty as to the classification of the nature of section 65 damages. This article seeks to evaluate the arguments of whether these damages actions should be properly classified as statutory or delictual actions by the South African civil courts.
\end{abstract}

\section{Keywords}

Competition law; damages; private competition damages; delictual; statutory. 


\section{Introduction}

It is apparent from the wording of South Africa's Competition Act 89 of 1998 (the Act) that the legislature envisaged the enforcement of both administrative penalties ${ }^{1}$ as well as civil damages ${ }^{2}$ against contravening firms or individuals. However, in order to properly assess the nature of these remedies, one needs to consider the underlying philosophical basis of the different remedies provided for in the Act.

The courts have acknowledged the different objectives sought to be achieved by civil damages and administrative penalties. Civil damages are pursued to address private wrongs (corrective justice), whereas administrative penalties imposed by the Tribunal are made in the public interest (distributive justice). ${ }^{3}$

\section{Justice advanced by the Competition Act 89 of 1998}

Distributive justice accepts the difficulties and limitations of placing victims in the position they would have been in had the contravention not occurred and focusses on achieving greater wellbeing of the public at large. ${ }^{4}$

The general wellbeing of the public lies in the investigation and prosecution of anti-competitive conduct in contravention of the Act and the enforcement of the statute in order to achieve the intended social welfare objectives. This engineers an active and fair competitive landscape from which the public (as consumers) can benefit. The imposition of administrative penalties against firms found to have contravened the Act is tantamount to promoting the objectives of distributive justice. Firms engaging in prohibited practices will be penalised, not for what damage was inflicted on any particular individual, but the administrative penalty will rather be imposed as a remedy to punish contravening conduct with a view to discouraging firms from acting in this manner in future. The greater objectives and interests of society at large are thereby protected. ${ }^{5}$

Malcom Ratz. BA LLB LLM (US) LLD (UP). Partner at Kruse Attorneys Incorporated, Pretoria, South Africa. Email: malcolm@rkattorneys.co.za.

Section 59 of the Competition Act 89 of 1998 (the Competition Act).

Section 65(6) of the Competition Act.

American Natural Soda Corporation v Competition Commissioner 20035 SA 633 (CAC) 639. Malan J states that: "the tribunal is not empowered to make orders for the payment of damages to any particular person (ss 62(5) and 65(5)): ... Essentially, as I have said, they are orders of a limited kind to be made in the public interest. They do not seek to vindicate private rights."

4 Vallentyne Date Unknown http://klinechair.missouri.edu/docs/distribu tive_justice_handbook.pdf.

5 Mbazira Litigating Socio-economic Rights 114-115. Chayes 1976 Harv L Rev 1281, 1294. Rawls Political Liberalism 16. See also Wellman "Justice" 70. 
Corrective justice seeks to place victims of prohibited practices in the position they would have been in, but for the contravening conduct. ${ }^{6}$ The right to restitution for the victims of prohibited practices in terms of the Act is a right expressly recognised by the Act. ${ }^{7}$. The role of corrective justice is often a double-edged sword. Its primary objective is to compensate victims, while simultaneously adding deterrent value against prospective contravening conduct.

The theory of distributive justice allows the enforced remedies to be prospective and centred on the needs of society. The competition authorities are, through the enforcement of penalties, enabled to deter future repetition of contravening conduct. In contrast, corrective justice is retrospective in nature, and focusses on addressing the harm suffered by the individual claimant. ${ }^{8}$

A 2008 study performed by Connor and Lande considered many examples of cartel overcharges. The authors observed a median cartel overcharge of approximately $25 \% .{ }^{9}$ A later study by Niels, Jenkins and Kavanagh concluded that the median overcharge achieved by cartels was approximately $18 \%$, and the average cartel overcharge was approximately $20 \% .{ }^{10}$ These studies indicate that cartels (save for unsuccessful cartels) gain significant additional profit by engaging in anti-competitive behaviour. This additional profit potentially renders an administrative penalty (capped at ten per cent of the turnover achieved in a single financial year) ${ }^{11}$ less of a financial threat, and/or deterrent than the legislature may have hoped. This poses the question: Does crime pay? ${ }^{12}$

This is of particular significance if one considers that South Africa's competition law regime has to date failed to successfully usher in a culture of private competition damages actions.

Penalties should be of such a magnitude that parties consider the threat of a penalty as sufficient deterrence. However, it is cautioned that excessive

6 Modak-Truran 2000 Yale J L \& Human 250. See also Gardner 2011 Law \& Phil 150.

7 See s 65(6) of the Competition Act.

8 Roach Constitutional Remedies 3-17. The perceived backward-looking nature of corrective justice is criticised in Gardner 2011 Law \& Phil 14: "a second and perhaps more pernicious misinterpretation of the contrast between corrective and distributive justice would have it that norms of corrective justice are sensitive to the past (they set 'backward-looking' grounds of allocation) whereas norms of distributive justice look to the future (they set 'forward-looking' grounds of allocation)".

$9 \quad$ Connor and Lande "Cartel Overcharges" 2208-2211.

$10 \quad$ Niels, Jenkins and Kavanagh Economics for Competition Lawyers 506.

11 See s 59(2) of the Competition Act.

12 Landes $1983 \cup$ Chi L Rev 652, 655: "despite the penalty, it still may be profitable to form the cartel. In our example, a $\$ 50$ fine will be too low. Firms would not forgo cartel profits of $\$ 100$ to avoid a $\$ 50$ fine". 
penalties could lead to inefficiencies within the competitive landscape that serve to prejudice society, instead of advancing the interests of society sought to be promoted by the imposition of the penalty. ${ }^{13}$

In order to deter the inclination of parties to pursue their own interests, rather than conform to the laws of society, it is necessary to attach sanctions and/or penalties to the contravention - including contraventions of the Act. If they are contemplating contravening the Act, these firms must know that their conduct will have a negative impact on their own financial welfare through the incurring of administrative penalties and civil damages. This double-edged sword will discourage firms from engaging in such illegal conduct. ${ }^{14}$

The interaction of both distributive and corrective justice shows how these two remedial objectives are both advanced by the Act. Distributive justice applies a remedy that will protect society from similar future contraventions (administrative penalties), and corrective justice is the compensatory remedy (private damages) of reparation for damage suffered by an individual as a result of the contravening conduct.

In South Africa the public enforcement objective has steadily developed, but the private enforcement and recovery of private damages (ie corrective justice) has significantly lagged behind. This not only results in a less effective enforcement of competition law, but also means that individuals suffering due to prohibited practices are not vindicating their right to pursue civil damages against contravening firms. Assessing the nature of the individual's right to civil damages, as contemplated in section 65 of the Act, it is necessary not only for individuals to achieve the compensation they are entitled to, but also for the advancement of a more efficient multi-faceted competition law enforcement regime.

\section{Driving justice through private competition damages actions}

The primary objective of South African law when dealing with damages claims is: "to compensate the person who has suffered harm", ${ }^{15}$ by placing the victim in the position they would have been in had the wrongful conduct not been committed. Private enforcement consequently serves as an additional (potentially greater) deterrent to firms from engaging in anticompetitive practices. It is in the best interests of the public and the

\footnotetext{
13 Landes $1983 \cup$ Chi $L$ Rev 652, 655 Also see Lianos 2011 https://www.ucl.ac.uk/drupal/cles/sites/cles/files/cles_3_2011new.pdf 3.

$14 \quad$ Wells and Eaton Constitutional Remedies 176.

$15 \quad$ Van der Walt and Midgley Principles of Delict 216.
} 
competition authorities to create an environment in which private damages claims for contraventions of the Act are encouraged and facilitated.

The South African Competition Act applies to all economic activity within or having an effect within South Africa. ${ }^{16}$ Section 65(6) of the Act states:

A person who has suffered loss or damage as a result of a prohibited practice-

(a) may not commence an action in a civil court for the assessment of the amount or awarding of damages if that person has been awarded damages in a consent order confirmed in terms of section $49 \mathrm{D}(1)$; or

(b) if entitled to commence an action referred to in paragraph (a), when instituting proceedings, must file with the Registrar or Clerk of the Court a notice from the Chairperson of the Competition Tribunal, or the Judge President of the Competition Appeal Court, in the prescribed form -

(i) certifying that the conduct constituting the basis for the action has been found to be a prohibited practice in terms of this Act;

(ii) stating the date of the Tribunal or Competition Appeal Court finding; and

(iii) setting out the section of this Act in terms of which the Tribunal or the Competition Appeal Court made its finding.

The Act contemplates that a person who has suffered loss or damage as a result of a prohibited practice shall commence a potential damages action in a civil court. ${ }^{17}$

This creates a two-phased adjudication process for civil damages actions arising from contraventions of the Act. The Competition Tribunal and the Competition Appeal Court adjudicate the conduct, and the civil courts are called upon to assess the damages (if any) arising from the conduct. ${ }^{18}$ Civil damages actions brought subsequent to the findings of the Competition Tribunal or Competition Appeal Court are commonly referred to as followon damages. ${ }^{19}$

16 Section 3(1) of the Competition Act. See also s 62(1).

17 Section 65(6)(b) of the Competition Act. Emphasis added.

18 The only exception to this two-phased adjudication jurisdiction appears to be the authority granted to the Competition Tribunal in terms of s 49D of the Competition Act to confirm consent orders that contain a damages award in favour of the victim(s) of the conduct. Van Heerden and Neethling Unlawful Competition 58: "the Competition Tribunal and Competition Appeal Court have no jurisdiction over the assessment of the amount, and awarding, of damages arising from prohibited practice". See also American Natural Soda Corporation v Competition Commission 20035 SA 633 (CAC) 639-640.

19 Brassey et al Competition Law 327. Sutherland and Kemp Competition Law 12-7. Niels, Jenkins and Kavanagh Economics for Competition Lawyers 493: "after a competition authority has found an infringement and imposed a remedy (often a fine), parties that have been harmed by the infringement may file a claim for 
The primary objective of follow-on damages is to compensate the victims of anti-competitive behaviour, but such actions serve as an additional deterrent, assisting public enforcement efforts and promoting compliance with the Act. Despite the clear gains to be had from private damages actions, it is surprising that approximately only $25 \%$ of the findings of a contravention by the European Commission have resulted in the victims' pursuing civil damages actions. ${ }^{20}$

Despite the Act's being in operation for more than 15 years, the first private damages action arising from a contravention of the Act in South Africa was made on 8 August 2016. ${ }^{21}$ The slow development of private competition damages actions in South Africa can be ascribed to various reasons, primarily the complexities of quantifying damages arising from anticompetitive conduct and the high cost of litigation in South Africa. Furthermore, most consumers lack the financial resources to bring a complex civil damages action against large corporate firms.

South African law relating to follow-on damages from contraventions of the Act is underdeveloped. Recent events provide some insight as to how follow-on damages actions may be facilitated in South Africa. These include the recent Supreme Court of Appeal ruling on class actions, which may significantly advance access for individuals to prosecute private competition damages claims, as well the views expressed on the nature of the damages action arising from contraventions of the Act. ${ }^{22}$

\subsection{Section 65 follow-on damages and the South African legal framework}

The Competition Tribunal and Competition Appeal Court have exclusive jurisdiction to adjudicate whether conduct is in contravention of the provisions of the Act.

Section 65(6)(b) of the Act states that a party pursuing an action for civil damages requires a certificate from the Chairman of the Competition Tribunal or the President of the Competition Appeal Court, certifying that the conduct forming the basis of the damages claim has been found to be a

damages against the infringer ... such 'follow-on' damages claims under competition law are increasingly common in many jurisdictions".

European Commission 2013 http://europa.eu/rapid/press-release_IP-13525_en.htm. In South Africa, the number of private damages actions arising from a finding of a contravention of the Competition Act are negligible.

$21 \quad$ Nationwide Airlines (Pty) Ltd (in Liquidation) v South African Airways (Pty) Ltd 2016 6 SA 19 (GJ).

22 Children's Resource Centre v Pioneer Food 20132 SA 213 (SCA); Nationwide Airlines (Pty) Ltd (in Liquidation) v South African Airways (Pty) Ltd 20166 SA 19 (GJ). 
prohibited practice in terms of the Act. ${ }^{23}$ The section 65 certificate is irrefutable confirmation of the contravention of the Act by the cited party. The civil courts are bound by this finding. ${ }^{24}$ The civil court will be required to assess the remaining elements of causation and the extent of the damages caused by the contravening conduct. ${ }^{25}$

Section 65 of the Act requires that when follow-on damages are claimed, a two-phased approach has to be adopted. First, the Competition Tribunal and/or Competition Appeal Court must determine whether the Act has been contravened, and second, the civil courts are tasked with assessing the damages and whether the contravention caused the loss claimed. ${ }^{26}$ The question that this raises is whether follow-on damages sanctioned by section 65 of the Act are to be viewed as common law delictual claims or statutory damages claims. ${ }^{27}$

In Children's Resources Centre $v$ Pioneer Foods ${ }^{28}$ the parties offered differing interpretations of section $65 .{ }^{29}$ Clarifying the nature of section 65 damages claims is fundamental for the purposes of understanding who may institute such a claim, as well as the scope of the onus to be discharged by a claimant.

23 This means that a plaintiff in such a damages claim is essentially relieved not only of showing conduct, but also of showing unlawfulness in a damages claim resulting from an infringement of the Competition Act. These elements would have been predetermined by the relevant Competition Tribunal and are then evidenced by the s 65(6)(b) certificate.

24 Section 65(2) of the Competition Act states the following: "If, in any action in a civil court, a party raises an issue concerning conduct that is prohibited in terms of this Act, that court must not consider that issue on its merits, and - if the issue raised is one in respect of which the Competition Tribunal or Competition Appeal Court has made an order, the court must apply the determination of the Tribunal or the Competition Appeal Court to the issue...".

25 Scallan, Mbikiwa and Blignaut 2013 http://www.compcom.co.za/wpcontent/uploads/2014/09/Conference-Paper-Final-21-08-2013.pdf.

26 For the purposes of $\mathrm{S} 65$ damages actions, the contravention verdict by the Competition Tribunal would mean that certain of the requirements for common law civil liability, notably conduct, unlawfulness and fault, have already been established and need not, and in fact cannot, be reconsidered by the civil courts.

27 The debate as to the categorisation of competition damages actions is not unique to South Africa. The English courts are also faced with the issue of the type of damages claim that arises from statutory contraventions. See WH Newson Holding Ltd v IMI PIC [2013] EWCA Civ 1377, where the court found that s 47A damages are not limited to claims of breach of a statutory duty. Also see WH Newson Holding Ltd $v$ IMI PIC [2012] EWHC 3680 (Ch) 29, where Roth J with reference to the scope of $\mathrm{s}$ $47 \mathrm{~A}$ damages states that such a claim is not restricted to one arising from a statutory duty, but rather, that one is to consider "the factual nature of the claim, not the cause of action with which it is clothed".

$28 \quad$ Children's Resource Centre v Pioneer Food 20132 SA 213 (SCA).

29 The appellants (Children's Resource Centre) argued an interpretation in favour of $S$ 65 's creating a delictual claim upon which the subsequent damages action is to be based. The respondent (Pioneer) argued that the claim referred to in s 65 was based solely on statute. 


\subsection{Children's Resource Centre v Pioneer Food and follow-on damages}

\subsubsection{Follow-on damages claim}

During November 2010 representatives acting on behalf of consumers ${ }^{30}$ and distributors ${ }^{31}$ brought an application for the certification of a class action for damages suffered by the respective groups arising from the increase in bread prices manipulated by the cartel. The Western Cape High Court dismissed both the applications for the certification of a class and the parties applied for leave to appeal to the Supreme Court of Appeal. ${ }^{32}$

The consumers' application for the certification of a class (Children's Resource Centre) ${ }^{33}$ was favourably received by the Supreme Court of Appeal. This acceptance augurs well for significant developments in the South African law of class actions and subsequent follow-on damages claims. Establishing requirements for the certification of a class for the purposes of instituting a class action is a step in the right direction. Consequently, the consumers' appeal was upheld and the Supreme Court of Appeal ordered that the matter be referred back to the Western Cape High Court for the filing of further affidavits. ${ }^{34}$

The development of class actions in the South African context is a major advance, as this will undoubtedly support the ability of consumers to gain access to the courts, thereby facilitating the vindication of individual rights to recover damages from contravening parties.

A fundamental issue to be considered is the basis of the damages assessment to be undertaken and proven. The Supreme Court of Appeal was not tasked with assessing the nature of the damages claim, but Wallis

30 Children's Resource Centre Trust v Pioneer Foods (Pty) Ltd; Mukaddam v Pioneer Foods (Pty) Ltd 2011 ZAWCHC 102 (7 April 2011).

$31 \quad$ Mukaddam v Pioneer Foods (Pty) Ltd 20135 SA 89 (CC).

32 Children's Resource Centre Trust v Pioneer Foods (Pty) Ltd; Mukaddam v Pioneer Foods (Pty) Ltd 2011 ZAWCHC 102 (7 April 2011). Also see Children's Resource Centre v Pioneer Food 20132 SA 213 (SCA); Mukaddam v Pioneer Foods (Pty) Ltd 20132 SA 254 (SCA).

$33 \quad$ Mukaddam v Pioneer Foods (Pty) Ltd 20135 SA 89 (CC).

34 Children's Resource Centre v Pioneer Food 20132 SA 213 (SCA). Importantly, the consumers' certification application was sought in terms of both the complaints; first, in respect of the Western Cape complaint and second, with regard to the national complaint against the bread producers. The SCA upheld the consumer's application only insofar as it related to the Western Cape complaint and dismissed the appeal relating to certification of the class for the national complaint. 
$\mathrm{JA}^{35}$ dealt to a limited degree with this question, before remitting the matter back to the High Court. ${ }^{36}$

\section{Children's Resource Centre ruling: section 65 - delictual or statutory?}

Wallis $\mathrm{JA}^{37}$ was faced with two conflicting interpretations of section 65 of the Act. The consumers argued that a claim for damages in the current context should be assessed as a delictual action flowing from a breach of statutory duty. Premier (the third respondent) interpreted section 65 of the Act as creating a statutory claim to the exclusion of a delictual or other commonlaw remedy. ${ }^{38}$

Wallis JA recognised the importance of this debate. He noted that if Premier was correct in its assertion that the Act provides for an exclusive follow-on statutory claim, then there was no recognised legal duty attaching to the breach, and the consumer's argument that damages were claimed by delictual action could not succeed. However, Wallis JA conceded that if Premier's submission was incorrect, then the argument by the consumers was strengthened. Section 65(6) of the Act recognises the right to claim damages for harm suffered as a result of contraventions (i.e. prohibited practices) of the Act. The absence of a specific statutory claim would mean that there must be a delictual remedy available to the injured parties. ${ }^{39}$

\subsection{Section 65: delictual action for damages}

In South Africa common-law actions for damages are brought either in terms of the actio legis Aquiliae or in terms of the actio injuriarum. Where loss due

$35 \quad$ Children's Resource Centre v Pioneer Food 20132 SA 213 (SCA). states: "... in summary the claim that the appellants seek to advance has a potentially plausible basis, but it is premature at the stage of this appeal for this court to determine questions raised by these arguments in view of their novelty, complexity and the fact that they are raised for the first time in this court. The appellants should not be non-suited on these grounds, which would be the effect of dismissing their appeal, but equally the respondents' arguments cannot be rejected at this stage. That indicates that it is desirable to refer the present application back to the high court, with appropriate directions for the delivery of further affidavits ..."

37 Children's Resource Centre v Pioneer Food 20132 SA 213 (SCA) 242-244.

$38 \quad$ Children's Resource Centre v Pioneer Food 20132 SA 213 (SCA) 242-244.

39 Children's Resource Centre v Pioneer Food 20132 SA 213 (SCA) 244: "... the legal arguments about the existence of a legal duty and the existence of an exclusive statutory claim in terms of $s 65$ of the Act are linked. If Premier is correct that the Act provides an exclusive follow-on claim then the legal duty on which the appellants rely does not exist. However, if it is incorrect, that strengthens the appellants' hand considerably, because $S$ 65(6) recognises the possibility of claims arising from prohibited anti-competitive conduct, so that the absence of a specific statutory claim would suggest that there must be a delictual claim available to at least some persons injured by such conduct". 
to the unlawful and culpable damage to a patrimonial interest occurs, damages are claimed using the actio legis Aquilae. ${ }^{40}$ If a non-patrimonial interest (e.g. the physical or mental integrity of a person) is compromised by unlawful and intentional conduct, non-patrimonial damages (injury to personality rights) using the actio iniuriarum are claimed. ${ }^{41}$

It is impossible to postulate a contravention of the Act that could infringe rights of personality, as the provisions of the Act, particularly those constituting prohibited practices triggering section 65 private damages actions, do not contemplate or recognise such infringements as contraventions of the Act. Where a damages claim is instituted for a prohibited practice, the nature of the damage will consequently be patrimonial. and such damage must be claimed using the actio legis Aquiliae. $^{42}$

In South Africa the actio legis Aquiliae has developed into a far more encompassing action than its rigid Roman law genesis, and subsequent Roman-Dutch law evolution. ${ }^{43}$ South African courts have progressively developed the scope of the actio legis Aquliae from the Roman-Dutch position. De Villiers states in The Cape Good Hope Bank that: "the action in factum was no longer confined to cases of damage done to corporeal

40 Potgieter, Steynberg and Floyd Visser and Potgieter Law of Damages 6. In Coronation Brick (Pty) Ltd v Strachan Construction Co (Pty) Ltd 19824 SA 371 (D) 377 Booysen states: "... in essence the Aquilian action lies for patrimonial loss caused by wrongfully (or unlawfully) and culpably". Also see Perlman v Zoutendyk 1934 CPD 151 155; Greenfield Engineering Works (Pty) Ltd v NKR Construction (Pty) Ltd 19784 SA 901 (N); Franschoekse Wynkelder (Ko-op) Bpk v SAR \& H 1981 3 SA 36 (E) 430; Lillicrap, Wassenaar and Partners v Pilkington Brothers SA (Pty) Ltd 19851 SA 475 (A).

$41 \quad$ Van Heerden and Neethling Unlawful Competition 68. The distinction between a claim for patrimonial and non-patrimonial loss is discussed in Matthews $v$ Young 1922 AD 492. Also see Bredell v Pienaar 1924 CPD 203 213; Universitiet van Pretoria v Tommie Meyer Films (Edms) Bpk 19774 SA 376 (T) 385; Moaki v Reckitt and Colman (Africa) Ltd 19884 SA 63 (D) 65; Brenner v Botha 19563 SA 257 (T) 260.

42 Geary \& Son (Pty) Ltd v Gove 19641 SA 434 (A) 441A. Justice Steyn states that "I do not propose to attempt a definition of the limits set to competition in trade by Aquilian liability, but whatever those limitations are, it seems clear that interference of the nature indicated is recognised as an infringement of a trader's rights and therefore a delict in our law". Also see William Grant and Sons Ltd v Cape Wine Distillers Ltd 19903 SA 897 (C) 915, where Justice Berman stated: "... in South Africa unlawful competition is recognised as an actionable wrong ... fitting comfortably under the umbrella provided by the lex Aquilia".

43 Traditionally, Roman law restricted the action to corporeal damage (ie damage to property or assets). See Van den Heever Aquilian Damages 8-14. The application of the action was later extended by Roman-Dutch law. It appears that there was a move away from the requirement of physical impairment of property. See Cape of Good Hope Bank v Fischer (1886) 4 SC 368. Further, the Acquilian action could be used to claim damages for injury to personality. See Neethling, Potgieter and Visser Neethling's Law of Personality 48. See Van Heerden and Neethling Unlawful Competition 70-71. Also see Neethling, Potgieter and Visser Law of Delict 8-16. 
property, but was extended to every kind of loss sustained by a person as a consequence of the wrongful acts of another". ${ }^{44}$ The current South Africa Aquilian action is a modern adaptation and application of the classical Aquilian action. Aquilian liability may now result from every culpable and wrongful act that results in patrimonial loss being suffered. ${ }^{45}$

Within the context of damages arising from unlawful competition, the courts have long accepted that such loss should be recovered by way of the action legis Aquiliae. ${ }^{46}$

While the South African Aquilian action may allow for a far more liberal application than that originally envisaged by the Romans, its application is somewhat tempered in the context of damages arising from the contravention of a statute (presently the Competition Act). Damage in this instance will be limited to the type of damage contemplated by the legislature when enacting the statute for the benefit of a particular person or group of persons.

Cape of Good Hope Bank v Fischer (1886) 4 SC 368 376. Also see Matthews v Young 1922 AD 492 504; Bester v Commercial Union Versekeringsmaatskapy van SA Bpk 19731 SA 769 (A) 776-777.

45 Perlman v Zoutendyk 1934 CPD 151 155, where Watermeyer states that: "RomanDutch Law approaches a new problem in the continental rather than English way, because in general all damage caused unjustifiably (injuria) is actionable, whether caused intentionally (dolo) or by negligence (culpa)".

46 Matthews $v$ Young 1922 AD 492 507: "... all a person can, therefore, claim is the right to exercise his calling without unlawful interference from others. Such interference would constitute an injuria for which an action under the lex Aquilia lies if it has directly resulted in loss". Also see Geary \& Son (Pty) Ltd v Gove 19641 SA 434 (A) 440-441, where Steyn recognises that the Aquilian action is available to persons suffering loss as a result of unlawful competition and who elects to sue in delict. Also see inter alia Geary \& Son (Pty) Ltd v Gove 19641 SA 434 (A); Atlas Organic Fertilizers (Pty) Ltd v Pikkewyn Ghwano (Pty) Ltd 19812 SA 173 (T); Lorimar Productions Incorporated $v$ Sterling Clothing Manufacturers (Pty) Limited; Lorimar Productions Incorporated $v$ OK Hyperama Limited; Lorimar Productions Incorporated v Dallas Restaurant 19813 SA 1129 (T); Dun and Bradstreet (Pty) Ltd v SA Merchants Combined Credit Bureau (Cape) (Pty) Ltd 19681 SA 209 (C); Link Estates (Pty) Ltd v Rink Estates (Pty) Ltd 19792 SA 697 (E); Victor Products (SA) (Pty) Ltd v Lataleure Manufacturing 19751 SA 961 (W); Stellenbosch Wine Trust v Oude Meester Group 19723 SA 152 (C); Stellenbosch Wine Trust v Oude Meester Group 19772 SA 221 (C); Prok Africa (Pty) Ltd v NTH (Pty) Ltd 19803 SA 687 (W); Silver Crystal Trading v Namibia Diamond Corporation 19834 SA 884 (D); Sea Harvest Corporation v Irvin \& Johnson 19852 SA 355 (E); Schultz v Butt 19863 SA 667 (A); Moroka Swallows Football Club v The Birds Football Club 19882 SA 350 (W); Sibex Construction v Injectaseal 19882 SA 54 (T); Elida Gibbs v Colgate Palmolive 19882 SA 350 (W); Pepsico Inc v United Tobacco Co Ltd 19882 SA 334 (W); William Grant and Sons Ltd v Cape Wine Distillers Ltd 19903 SA 897 (C); Long John International v Stellenbosch Wine Trust 19904 SA 136 (D); Tie Rack plc v Tie Rack Stores 19894 SA 427 (T); Sage Holdings v Financial Mail 19912 SA 117 (W); Times Media v SABC 19904 SA 604 (W). 


\subsection{Arguments favouring section 65 damages as delictual action}

The essence of the argument by the consumers in Children's Resource Centre $^{47}$ is that once the Competition Tribunal or the Competition Appeal Court has made a finding that the defendant contravened the Act, then a party suffering loss or damage as a result of the contravention must allege and prove all the elements of a delict in order to successfully pursue its civil damages. The consumers (appellants in the Supreme Court of Appeal) argued that the Act prohibits anti-competitive conduct in the interest of promoting competition and benefitting the interests of consumers. ${ }^{48}$ The prohibitions contained in the Act are essential to achieving the objectives of the Act and create a fair environment within which consumers are not exploited, and receive a variety of quality products at competitive prices. ${ }^{49}$

South African case law lends support to the proposition that the existence of a statutory duty not to act in a certain way results in a legal duty not to cause financial loss. ${ }^{50}$ This was echoed by the appellants (the consumers) in Children's Resource Centre in the context of the Competition Act. The bread producers had a legal duty not to cause financial loss and their contravention of the provisions of the Act was in breach of this legal duty. Ultimately, the breach by the bread producers resulted in the consumers paying higher prices for bread and consequently suffering financial harm. ${ }^{51}$ Essentially: "the appellants have now nailed their colours to the mast of a delictual action flowing from a breach of a statutory duty". ${ }^{52}$

\subsection{Arguments favouring section 65 being a statutory claim}

Pioneer (First Respondent) ${ }^{53}$ advanced the argument that section 38(c) of the Constitution ${ }^{54}$ recognises proceedings for appropriate relief on the grounds of an infringement of any right in the Bill of Rights by "anyone acting as a member, or in the interests of, a group or class of persons". Although the instituting of class actions is recognised insofar as the enforcement of a constitutional claim and claims relating to the Bill of Rights is concerned, the

$47 \quad$ Children's Resource Centre v Pioneer Food 20132 SA 213 (SCA).

$48 \quad$ Children's Resource Centre v Pioneer Food 20132 SA 213 (SCA) 243.

49 See s 2(b) of the Competition Act.

$50 \quad$ Steenkamp v Provincial Tender Board, Eastern Cape 20063 SA 151 (SCA); Olitzki Olitzki Property Holdings v State Tender Board 20013 SA 1247 (SCA). The ruling given in Lascon Properties (Pty) Ltd v Wadeville Investment Co (Pty) Ltd 19984 SA 578 (W) erroneously suggested that the breach of a statutory duty automatically implies that a delict has been committed. This is incorrect, as in order for a claimant to successfully institute a delictual claim all the elements of a delict must be proven (ie conduct, damage and causation). See Steenkamp v Provincial Tender Board, Eastern Cape 20073 SA 121 (CC) 139. 
recognition of class actions in the Constitution does not confer standing in relation to a delictual claim. ${ }^{55}$ This argument was dismissed by Wallis JA. ${ }^{56}$

Premier (Third Respondent) argued that the appellants' delictual action be dismissed because the Competition Act was not enacted for the benefit of the parties who had sought to institute the damages claim, and therefore the necessary legal duty giving rise to delictual liability had never been established. ${ }^{57}$ It was further argued that the fundamental elements of the delictual action, of damages and the necessary causal connection between the alleged conduct and damage suffered, had not been proven by the appellants.

Premier adopted the view that section 65 of the Act provides for follow-on damages, based on the finding by the Competition Tribunal that the firm had engaged in anti-competitive conduct in contravention of the Act. A proper construction of the Act, insofar as Premier was concerned, is that the damages claim is exclusive to section 65 , thereby prohibiting a commonlaw delictual action. ${ }^{58}$

Firstly, Premier argued that the Act created a specialist regime for dealing with competition law issues (including whether a party has engaged in prohibited practices) and if a contravention occurs, how it should be penalised. ${ }^{59}$ The bifurcation of jurisdiction created by the Act meant that ordinary civil courts are afforded an extremely limited role in relation to the cause of action arising from the Act. This was restricted to the assessment of or the awarding of damages. Accordingly, the ordinary civil courts had no

55 Heads of Argument filed by the First Respondent, Children's Resource Centre $v$ Pioneer Food 20132 SA 213 (SCA) para 4. Essentially Premier argued that in order for a delictual remedy for a breach of a statute to be relied upon, the necessary evidentiary requirements had to be met, including showing that the applicable statute allowed the particular party to bring such a claim.

Children's Resource Centre v Pioneer Food 20132 SA 213 (SCA) para 21: Wallis JA stated: "... in my judgment it would be irrational for the court to sanction a class action in cases where a constitutional right is invoked, but to deny it in equally appropriate circumstances, merely because of the claimants' inability to point to the infringement of a right protected under the Bill of Rights. The procedural requirements that will be determined in relation to the one type of case can equally easily be applied in the other. Class actions are a particularly appropriate way in which to vindicate some types of constitutional rights, but they are equally useful in the context of mass personal injury cases or consumer litigation".

$57 \quad$ Children's Resource Centre v Pioneer Food 20132 SA 213 (SCA) 243.

58 Children's Resource Centre v Pioneer Food 20132 SA 213 (SCA) 243. See Steenkamp v Provincial Tender Board, Eastern Cape 20063 SA 151 (SCA) para 22: "... one has to concede that our case law is not clear when it comes to drawing the boundary between liability due to the breach of a statutory duty and that of a common-law one. It appears to me that if the breach of a statutory duty, on a conspectus of the statute, can give rise to a damages claim, a common-law legal duty cannot arise".

59 Competition Commission of South Africa v Telkom SA Ltd 2010 All SA 433 (SCA) paras 27, 36. 
power to freely determine whether a delict had been proved and what the appropriate damages in the given situation should be.

Secondly, Premier contended that a proper interpretation of the Act restricted the circumstances in which civil damages would be available. This would be only after the Competition Tribunal or Competition Appeal Court had made a final ruling on the matter, and only if the injured party had not been awarded damages in terms of a consent order. ${ }^{60}$ This, Premier submitted, was an extraordinary limitation, not generally associated with normal delictual claims. This lent support to the position that section 65 damages actions must be managed within the auspices of the Act, and not as normal delictual actions.

Finally, Premier argued that the Act provided for strict liability. ${ }^{61}$ Claimants pursuing damages actions were absolved from having to prove fault (either negligence or intent) on the part of the contravening firm. A claimant could not simultaneously benefit from a regime of strict liability imposed by the statute, while endeavouring to avoid the other statutory requirements and limitations imposed on civil damages claims by the self-same statute, i.e. the Competition Act, in order to advance its common-law claim. To this extent, one of the limitations imposed was that the Act allowed a person who had suffered loss or damage to pursue a damages action before the civil court. The present matter envisaged an action by a class for damages arising from the contravention of the Act. Premier argued that a damages action brought by a class fell outside the scope of the statutory action envisaged by the Act and accordingly should not be entertained by the courts. ${ }^{62}$

If regard is had for the remedial philosophy of the respective remedies (administrative penalties and the civil damages actions) then Premier's argument to exclude class actions seems to carry some weight. The damages claim by a class action fails to serve the remedial purpose

60 Section 65(6)(a) of the Competition Act.

61 Heads of Argument filed by the Third Respondent, Children's Resource Centre $v$ Pioneer Food 20132 SA 213 (SCA) para 22.4.

62 This proposition was dismissed by Wallis JA in Children's Resource Centre v Pioneer Food 20132 SA 213 (SCA) para 21. Wallis JA stated: "... in my judgment it would be irrational for the court to sanction a class action in cases where a constitutional right is invoked, but to deny it in equally appropriate circumstances, merely because of the claimants' inability to point to the infringement of a right protected under the Bill of Rights. The procedural requirements that will be determined in relation to the one type of case can equally easily be applied in the other. Class actions are a particularly appropriate way in which to vindicate some types of constitutional rights, but they are equally useful in the context of mass personal injury cases or consumer litigation". 
advanced by corrective justice. It does not rectify the wrong to the private individual. ${ }^{63}$

Premier's arguments that the Act envisages a rigid statutory damages regime and as such a party (and the courts) will be obliged to follow the action as directed by the applicable statute may be credible if, by way of analogy, regard is had to the position expressed by the Constitutional Court in the matter of Phillips $v$ National Director of Public Prosecutions. ${ }^{64}$ The court was required to decide whether the High Court was permitted to rescind an order on grounds other than those specified in the Prevention of Organised Crime Act 121 of 1998. The Constitutional Court took a very narrow view, stating that: "I do not think that an Act of Parliament can simply be ignored and reliance placed directly on a provision in the Constitution, nor is it permissible to side-step an Act of Parliament by resorting to the common-law". 65

Should Premier's interpretation be attributed to section 65 of the Act, then parties and the courts will be bound by the provisions of the Act, including the statutory limitations sought to be imposed on these damages actions by the wording or the empowering statute.

\subsection{Assessment of section 65}

The Supreme Court of Appeal did not make a finding as to whether section 65 damages should be considered a delictual action or statutory, remitting the matter back to the High Court for the filing of further affidavits in amplification of the arguments. ${ }^{66}$

The fundamental difference between a delictual action and statutory action hinges on the elements that need to be proven for a claimant to succeed with the claim. In a statutory damages action, based on strict liability (the

63 Heads of Argument filed by the Appellants, Children's Resource Centre $v$ Pioneer Food 20132 SA 213 (SCA) para 6.2: "... the payment of damages to each individual member of the classes would not be feasible. Even were it possible to determine how much of the respondents' bread each individual consumer bought during the relevant periods, the damage suffered by each individual are relatively small and the cost of distributing these sum prohibitive. Accordingly, the damages will not be distributed to individual members of the classes ..."

$64 \quad$ Phillips v National Director of Public Prosecutions 20061 SA 505 (CC).

65 Children's Resource Centre v Pioneer Food 20132 SA 213 (SCA) paras 50-51.

66 Children's Resource Centre v Pioneer Food 20132 SA 213 (SCA) para 75, (247): "... in summary the claim that the appellants seek to advance has a potentially plausible basis, but it is premature at the stage of this appeal for this court to determine questions raised by these arguments in view of their novelty, complexity and the fact that they are raised for the first time in this court. The appellants should not be non-suited on these grounds, which would be the effect of dismissing their appeal, but equally the respondents' arguments cannot be rejected at this stage. That indicates that it is desirable to refer the present application back to the high court, with appropriate directions for the delivery of further affidavits..." 
claimant need not allege and prove fault), a breach of a statute is prima facia wrongful and fault is not a requirement. ${ }^{67}$ Should a strict statutory regime be followed for the recovery of private competition damages in terms of section 65 of the Act, then these actions are equally restricted by the provisions of the Act, including possibly limiting such claims to individuals, to the exclusion of classes.

A delictual action requires the claimant to prove the elements of wrongfulness and fault to succeed with the claim, together with all the other elements of a delictual action.

Ultimately, the question is whether a proper reading of section 65 in the context of the Act allows for the interpretation of a statutory damages action to the exclusion of a common law delictual damages action.

The wording of section 65(6) of the Act, which reads: "a person who has suffered loss or damage as a result of a prohibited practice...", clearly envisages that any person who has suffered loss or damage as a result of a contravention of Chapter 2 of the Competition Act may claim such loss. ${ }^{68}$ Despite recognising the potential of a damages claim's being brought, section 65 does not provide any detail or requirements for such an action. Rather, section 65 appears to merely regulate the practical jurisdictional aspects pertaining to the adjudication of potential contraventions of the Act on the one hand, and on the other the adjudication and assessment of a follow-on damages action arising from a contravention of the Act.

Section 65(2) confirms that the Competition Tribunal and Competition Appeal Court adjudicate the conduct and sections 65(6) and 65(7) confirm that the civil courts assess and award civil damages. Thus, the two-phased approach to follow-on damages in the context of contraventions of Chapter 2 of the Act is established. Premier argued that it is the very fact that a twophased procedure has been created which supports the notion of strict

67 Neethling, Potgieter and Visser Law of Delict 78; Van Heerden and Neethling Unlawful Competition 253. While the distinction between statutory claims and delictual claims can be seen in the elements required to be alleged and proven in each case, this is not the only difference between these actions, as statutory actions also provide a more comprehensive description of the extent of the damage which can be claimed, thereby creating a damages system separate from the normal common-law delictual damages actions and assessment of damages. The Compensation for Occupational Injuries and Diseases Act 130 of 1993 is an example of a statute creating a statutory damages regime. $S 47(1)(a)$ of the Act reads as follows: "Compensation for temporary total disablement shall be calculated on the basis set out in item 1 of Schedule 4 subject to the minimum and maximum amounts." Schedule 4 then specifies the manner in which damages will be calculated in various instances. 
statutory liability. ${ }^{69}$ The Act creates a specialist tribunal with exclusive jurisdiction to determine whether or not a prohibited practice has been committed, and the civil courts' involvement is limited to the assessment and determination of follow-on damages. ${ }^{70}$

In assessing the respective arguments regarding the nature of the follow-on damages action, Wallis JA acknowledged that certain aspects of section 65 lend support to the interpretation advanced by Premier, highlighting sections 65(6)(a) and 49D(4) as examples. Section 65(6)(a) refers to a person who has suffered loss or damage as a result of a prohibited practice commencing an action in the civil court for the assessment of the amount or awarding of damages. Wallis JA referred to the wording of section 65(6)(a) of the Act that could indicate that the action pursued before the civil court concerns only the quantification of the damage suffered and nothing more. ${ }^{71}$ Furthermore, Wallis JA referred to section 49D(4) of the Act, which deals with a complainant's applying for an award of civil damages. He acknowledged that this section appears to support the notion advanced by Premier that the damages award is a rigid mechanical process, in which the civil court is tasked only with the assessment of the damage, and not required to consider any element other than quantification. ${ }^{72}$

It must be noted that section 49D(4) reads:

A consent order does not preclude a complainant from applying for -

(a) a declaration in terms of section $58(1)(a)$ (v) or (vi); or

(b) an award of civil damages in terms of section 65, unless the consent order includes an award for damages to the complainant.

If regard is had to the wording of section $49 D(4)$, then it is entirely unclear how Wallis JA considered section $49 \mathrm{D}(4)$ as lending support to the

69 Sutherland and Kemp Competition Law 12-8: "... if a party seeks damages in respect of a prohibited practice it must seek a declaration from the Tribunal that the conduct of the respondent is a prohibited practice in terms of the Act, for the purpose of section 65. A person who has suffered loss or damage as a result of the prohibited practice may rely on such a declaration to bring an action in the Magistrate's Court or the High Court to recover damages in this respect". Also see the following cases, which lend strong support that the provisions of s 65 create a two-tiered adjudication process for the assessment and awarding of damages, with a regulated procedural interaction between the various competition authorities and the civil courts, each responsible for a specific limited part of the adjudication process: Premier Foods (Pty) Ltd v Manoim 20161 SA 445 (SCA); Seagram Africa (Pty) Ltd v Stellenbosch Farmers' Winery 20012 SA 1129 (C) 1142; SAD Holdings $v$ South African Raisins 20003 SA 766 (T); South African Raisins (Pty) Ltd v SAD Holdings Ltd 20012 SA 877 (SCA); American Natural Soda Corporation v Competition Commissioner 2003 5 SA 633 (CAC) 639.

$70 \quad$ Children's Resource Centre v Pioneer Food 20132 SA 213 (SCA) 245.

71 Children's Resource Centre v Pioneer Food 20132 SA 213 (SCA) 246.

72 Children's Resource Centre v Pioneer Food 20132 SA 213 (SCA) 246. 
argument that the damages claim is one found in statute. Other than to suggest that the parties should not include an amount for damages in a consent order, section $49 \mathrm{D}(4)$ does not provide a mechanism for establishing or dealing with damages. It is only when a settlement inclusive of damages is reached that it is ordered that a claim for damages as provided for in section 65 is excluded. Section 65(6) states that such a damages action will commence in the civil courts for the assessment and awarding of damages. Contrary to what Wallis JA states, a conjunctive reading of section 65 and section 49D(4) does not support the conclusion that the Act has created a statutory damages claim, but rather confirms that the civil courts are responsible for the assessment and awarding of damages.

\subsection{Interpretation of section 65 as a cause of action}

The Supreme Court of Appeal was reluctant to take a firm position regarding the question of whether section 65 of the Act creates a statutory or a delictual damages claim for the victims of prohibited conduct in terms of the Act. While the Supreme Court of Appeal steered away from making any conclusive remarks on the subject, an evaluation and interpretation of the relevant statutory provisions is nonetheless required.

When interpreting a statutory provision, regard must be had for the intention of the legislature. In order to do this, the words of the statute under consideration must be given their normal grammatical meaning, unless this would lead to an entirely untenable meaning being attributed thereto. ${ }^{73} \mathrm{In}$ cases where the words conceivably are not restricted to a single grammatical meaning or interpretation, then regard has to be had for the context within which these words are used within the statute being interpreted, and the purpose being promoted by the particular statute. ${ }^{74}$

73 Public Carriers Association v Toll Road Concessionaries (Pty) Ltd 19901 SA 925 (A) 942-944. Smalberger J states: "... the primary rule in the construction of statutory provisions is to ascertain the intention of the Legislature. It is now well-established that one seeks to achieve this, in the first instance, by giving the words of the enactment under consideration their ordinary grammatical meaning, unless to do so would lead to an absurdity so glaring the Legislature count not have contemplated it". Also see Standard Bank Investment Corporation Ltd v Competition Commission; Liberty Life Association of Africa Ltd v Competition Commission 20002 SA 797 (SCA), Schultz J states: "... our Courts have, over many years, striven to give effect to the policy or object or purpose of legislation. This is reflected in a passage from the judgment of Innes CJ in Dadoo Ltd and Others $v$ Krugersdorp Municipal Council 1920 AD 530, 543. But the passage also reflects that it is not the function of a court to do violence to the language of a statute and impose its view of what the policy or object of a measure should be".

74 Bastian Financial Services (Pty) Ltd v General Hendrik Schoeman Primary School 20085 SA 1 (SCA); University of Cape Town v Cape Bar Council 19864 SA 903 (A) 941; Bato Star Fishing (Pty) Ltd v Minister of Environmental Affairs 20044 SA 490 (CC) para 89; Thoroughbred Breeders' Association v Price Waterhouse 20014 SA 
Applying the primary rule of interpretation of statutory provisions and giving the words used in section 65 their normal grammatical meaning, it appears that the legislature intended to remove the assessment and awarding of damages from the powers conferred upon the Competition Tribunal and Competition Appeal Court, by expressly stating in section 65 of the Act that damages actions are to be commenced in the civil court for the assessment and awarding thereof (provided damages have not been settled in a section 49D consent order). ${ }^{75}$

The legislature's intention to remove the assessment of damages from the jurisdiction of the Competition Tribunal and the Competition Appeal Court is confirmed by the wording of section $62(5)$ of the Act, which reads: ${ }^{76}$

62(5) For greater certainty, the Competition Tribunal and Competition Appeal Court have no jurisdiction over the assessment of the amount, and awarding, of damages arising out of a prohibited practice.

It is important to note that not all contraventions of the Act are classified as prohibited practices. Section 65(6) of the Act deals expressly with a damages action by a person who has suffered loss or damage as a result of a prohibited practice. ${ }^{77}$ The Act may, however, be contravened in manners other than those contemplated in Chapter 2. For example, Chapter 3 of the Act deals with mergers and the notification of mergers to the competition authorities. ${ }^{78}$ It is a contravention of the Act to implement a

551 (SCA) 600. Marais, Farlam and Brand JJA (concurring with Nienaber JA) stated that "... the days are long past when blinkered peering at an isolated provision in a statute was thought to be the only legitimate technique in interpreting it if it seemed on the face of it to have a readily discernible meaning".

75 Section 65(6)(a) of the Competition Act. The fact that s 49D contemplates a damages award between parties which would extinguish a potential s 65(6) damages action should not be seen to lend support to the notion that such damages are to be considered statutory damages. When dealing with s 49D, damages included in a consent order agreed to among the infringing party, the Competition Commission and the injured party, it is important to note that neither the Competition Tribunal nor Competition Commission are required to assess a victim's damages or determine a damages quantum. These damages agreed to in terms of $s 49 \mathrm{D}$ are equivalent to a settlement agreement between the parties. This therefore strengthens the regulatory nature of the Competition Act, with certain functions falling within the scope and jurisdiction of the Competition Commission, Competition Tribunal and Competition Appeal Court, and the assessment and quantification of damages in terms of $\mathrm{s} 65$ falling within the jurisdiction of the civil courts.

76 Emphasis added.

77 Prohibited Practice is defined in the Competition Act as a practice prohibited in terms of Chapter 2.

78 Section $13 \mathrm{~A}(3)$ of the Competition Act: "The parties to an intermediate or large merger may not implement that merger until it has been approved, with or without conditions, by the Competition Commission in terms of section 14(1)(b), the Competition Tribunal in terms of section 16 (2) or the Competition Appeal Court in terms of section 17." The Act further imposes a potential penalty against firms contravening the merger notification requirements prescribed by Chapter 3 of the Act; to this extent see s 59(1)(d) of the Act. 
merger without the required notification and subsequent approval thereof by the competition authorities. Such a contravention of the Act could equally result in a party's suffering damages and seeking recourse against the contravening parties before the civil courts. This would, however, fall outside the ambit of section 65(6) of the Act.

The suggested interpretation is further supported when examples of statutes which expressly create statutory damages actions are considered. These statutes include the Aviation Act 74 of 1962, the National Nuclear Regulator Act 47 of 1999, and the Post Office Act 44 of 1958. These statutes allow for damages to be dealt with in a manner other than through the normal principles associated with damages actions before the civil courts. As illustration, the Aviation Act, section 11(2) reads:

\begin{abstract}
Where material damage or loss is caused by an aircraft in flight, taking off or landing, or by any person in such aircraft, or by any article falling from any such aircraft, to any person on land or water, damages may be recovered from the owner of the aircraft in respect of such damage or loss, without proof of negligence or intention or other cause of action as though such damage or loss had been caused by his wilful act, neglect or default.
\end{abstract}

It is clear that the Aviation Act has expressly done away with the need for a claimant to prove the elements of a delictual action in order to claim damages in terms of the Act.

The Competition Act, section 65(6), has not expressly sought to stipulate a different means of establishing and assessing damages other than the application of the normal principles of damages as applied by the civil courts. All section 65(6) has done is regulate which forum will be authorised to assess damages, and by implication, which of the elements are required to be alleged and proven in order to be successful with a civil damages action for follow-on damages arising from a breach of the Act.

\title{
4.6 Conclusion: section 65 as a statutory or delictual action
}

While no ruling was made, and despite recognising the plausibility of the argument advanced by Premier, the court remarked that section 65 of the Act appears not to contain the necessary elements for establishing an exclusive statutory remedy such as was contended by Premier. ${ }^{79}$ Ostensibly, section 65 merely confirms the procedure and directs the forum for the follow-on damages claim and is not an independent action creating provision. The regulatory nature of section 65 supports the notion that the follow-on damages claim is a claim based on a delict. In the absence of an expressly-worded liability-creating provision and formula for the

79 Children's Resource Centre v Pioneer Food 20132 SA 213 (SCA) paras 67-68, 244. Wallis states: "I am not convinced that $s 65$ of the Act provides for the type of exclusive follow-on remedy for which Premier contends." 
determination of damages in the particular statute, the common-law principles of assessment of damages applies. ${ }^{80}$

The reluctance of the Supreme Court of Appeal to entertain the argument that section 65 sanctions a statutory damages action may stem from the fact that the court appeared open to the idea of allowing class actions to be pursued in the case of section 65 damages claims in order to properly vindicate the rights of prejudiced consumers. ${ }^{81}$ The liberal interpretation given by Wallis to the notion of a person who has suffered loss or damage being entitled to commence an action for delictual damages, in order to include class actions, seemingly puts an end to the argument that the extent of the potential damages action is narrowly and rigidly regulated by the provisions of the Act, seemingly favouring an interpretation that section 65 damages actions before the civil courts ought to be commenced as delictual actions recognised at common-law.

\section{Nationwide Airlines v South African Airways: a critical view}

The Gauteng High Court was tasked with adjudicating the first section 65 damages action in Nationwide Airlines (Pty) Ltd (in Liquidation) $v$ South African Airways. ${ }^{82}$

While this was undoubtedly an opportunity for South Africa to gain clarity on certain of the vexing aspects relating to follow-on damages actions, the court failed to provide any significant foundation upon which these actions can grow and develop, instead taking a disappointingly easy way out.

\subsection{Delictual claim}

In the very first line Nicholls $\mathrm{J}$ expressed the position that section 65 followon damages actions are to be classified as delictual actions. ${ }^{83}$

Children's Resource Centre v Pioneer Food 20132 SA 213 (SCA) paras 69, 245. See also Neethling, Potgieter and Visser Law of Delict 399-402; and Potgieter, Steynberg and Floyd Visser and Potgieter Law of Damages 452. JA stated: "... in my judgment it would be irrational for the court to sanction a class action in cases where a constitutional right is invoked, but to deny it in equally appropriate circumstances, merely because of the claimants' inability to point to the infringement of a right protected under the Bill of Rights. The procedural requirements that will be determined in relation to the one type of case can equally easily be applied in the other. Class actions are a particularly appropriate way in which to vindicate some types of constitutional rights, but they are equally useful in the context of mass personal injury cases or consumer litigation". 6 SA 19 (GJ).

$83 \quad$ Nationwide Airlines (Pty) Ltd (in Liquidation) v South African Airways (Pty) Ltd 2016 6 SA 19 (GJ) 22. Nicholls J stated: "... this is a delictual claim, the first of its kind ...". 
While the position adopted by Nicholls $\mathrm{J}$ in the classification of the nature of the follow-on damages claim is supported by the author, disappointingly Nicholls $\mathrm{J}$ provided no explanation as to the reasons for finding that this was a delictual claim. The failure to do so is particularly disappointing given the debate that had taken place in the Supreme Court of Appeal regarding the nature of the section 65 claim.

This tar-brush approach to the nature of the claim is further carried over to the assessment of causation, which is a fundamental aspect of any damages assessment. In dealing with causation, Nicholls $\mathrm{J}$ simply relied on the finding of the Competition Tribunal (confirmed by the Competition Appeal Court) that the conduct of South African Airways was the major cause of the decrease in volume of Nationwide's passengers and consequently Nationwide's loss. Nicholls $\mathrm{J}$ then stated "Those are findings which cannot be faulted but, in any event, to which this court is bound." 84

A civil court is bound by the findings of the competition authorities as set out in the section 65 certificate issued prior to the commencement of the civil damages action. The section 65(6)(b) certificate must be in the prescribed form: 85

(i) certifying that the conduct constituting the basis of the action has been found to be a prohibited practice in terms of this Act;

(ii) stating the date of the Tribunal or Competition Appeal Court finding; and

(iii) setting out the section of this Act in terms of which the Tribunal or the Competition Appeal Court made its finding.

The s65 certificate makes no reference to the merits of the civil claim and no binding finding on the civil court insofar as the assessment of the element of causation is concerned.

While civil courts may be well within their rights to consider the merits of the competition complaint referral and possibly assess the expert reports and evidence presented during the complaint referral proceedings, it is ultimately for the civil court to apply its mind in a fair and efficient manner in assessing the remaining elements of the delictual action, being causation and damages. The blank reliance on the finding of the Tribunal insofar as the causation element is concerned is submitted to be incorrect and fails to make use of the opportunity to guide civil courts on dealing with the assessment of damages actions brought in terms of section 65 of the Act.

$84 \quad$ Nationwide Airlines (Pty) Ltd (in Liquidation) v South African Airways (Pty) Ltd 2016 6 SA 19 (GJ) 32.

85 Emphasis added. 


\section{Conclusion}

A strong presumption exists that the legislature does not intend to alter the common-law, save where such an intention appears expressly from the applicable legislation. ${ }^{86}$ If the legislature intends for the statute to vary the operation of the common law by introducing strict liability, then the statute must make express reference to the remedies sought to be introduced and implemented for the purposes of the statute. ${ }^{87}$

For this reason, it is concluded that the nature of the damages action arising in terms of section 65 of the Act is that of a delictual action, as stated by Nicholls $\mathrm{J}$ in Nationwide Airlines, ${ }^{88}$ and not a statutory action, as proposed by Premier. A delictual action (unshackled by a restrictive statutory interpretation) gives proper effect to the legislative objective to promote a dualistic enforcement regime, whereby the interests of society at large and individual parties who have suffered private damages at the hands of a prohibited practice are adequately protected and advanced.

It can be argued that a statutory damages action based on strict liability would facilitate a more accessible system of follow-on damages, because claimants will be freed from the burden of having to allege and prove the elements to succeed with a delictual action. ${ }^{89}$ It must nonetheless be borne in mind that the Competition Tribunal (or Competition Appeal Court) would have made a finding on certain elements required for the purposes of a delictual action, and a claimant's evidentiary burden is already significantly eased. The delictual elements of conduct and the unlawfulness of the conduct would have been considered and determined by the Competition Tribunal (or Competition Appeal Court). The claimant will be required to show only that it is entitled to claim damages arising from the breach of statute, ${ }^{90}$ together with the remaining delictual elements of damage (and the extent of the damages) and causation.

It is submitted that precisely because of the complex nature of damages determination and the fact that not all breaches necessarily cause damages to individuals or the public, the legislator opted for the dual approach rather

Fedlife Assurance Ltd $v$ Wolfaardt 2002 SA 49 SA (SCA) para 16. Also see Steyn Uitleg van Wette 97, 153.

87 See s 47 of the Compensation of Occupational Diseases Injuries Act 130 of 1993.

$88 \quad$ Nationwide Airlines (Pty) Ltd (in Liquidation) v South African Airways (Pty) Ltd 2016 6 SA 19 (GJ).

89 Scallan, Mbikiwa and Blignaut 2013 http://www.compcom.co.za/wpcontent/uploads/2014/09/Conference-Paper-Final-21-08-2013.pdf 10.

90 The requirements are: (i) contravened statute was intended to give rise to a cause of action; (ii) claimant is a party for whose benefit the statutory duty exists; (iii) damage sustained was of the type contemplated by the legislature in the statute; (iv) provisions of the statute were in fact infringed; and (v) the claimant suffered damage as a result of the statutory infringement. 
than attempting to enact an action-creating and damages-quantifying formula. This conclusion is supported by the wording of section 65 , read in conjunction with section 49D(4). These sections are the only sections in the Act which deal with damages. Their wording confirms a prejudiced party's entitlement to damages, and makes it clear that damages are excluded only where they have been awarded as part of a consent order in pursuance of a settlement. In conclusion, the Competition Act of 1998 does not define damages. This being the case, it follows that when the legislator uses the concept of "damages" in the Act, this can be a reference to common law damages only.

Proving the elements of conduct, wrongfulness and fault could never be a serious stumbling block for follow-on damages arising from a breach of the Act, because this is covered by a finding of a contravention by the Competition Tribunal or Competition Appeal Court. ${ }^{91}$

Once the claimant has established that the provision of the statute allowing a damages action was enacted for the benefit of the claimant, together with the fact that the type of damage suffered by the claimant was the type of damage contemplated by the legislature when enacting the statutory provision, then this will form the basis for establishing the wrongfulness of the conduct and the right to pursue the damages action.

The Competition Act contemplates a broad range of claimants, allowing any person who has suffered loss or damage as a result of a contravention of the Act to bring an action for damages, essentially identifying a group of persons who could be considered the beneficiaries of the statutory provision. ${ }^{92}$

With the element of fault and wrongfulness being (for all practical purposes) essentially moot, the primary burden on a claimant seeking to enforce the right to claim damages, as provided for in section 65 of the Act, is to quantify

$91 \quad$ The positive conduct and subsequent intentional nature of the infringements referred to in the Competition Act are clear from the wording describing the prohibited conduct. These examples include: s 4(1) An agreement between firms...; s 4(1)(b)(i) directly or indirectly fixing a purchase price or selling price or any trading condition; s 4(1)(b)(ii) dividing markets by allocating customers, suppliers, territories, or specific types of goods or services; s 4(1)(b)(iii) collusive tendering; s 8(a) charging an excessive price; $s$ (b) refusing to give a competitor access to an essential facility. The Competition Act makes no reference to negligent or accidental contraventions of the Act and all the examples of prohibited conduct refer to positive actions taken by competitors (in the case of $s 4$ contraventions) and dominant firms (in the case of $\mathrm{s} 8$ or $\mathrm{s} 9$ contraventions). It is clear that the conduct described and prohibited by the Act is positive conduct and can subsequently be considered intentional conduct. Section 65(6)(a) of the Competition Act. 
the extent of the damage suffered as a result of the contravention of the Act and to prove that the defendants conduct caused the damage suffered. ${ }^{93}$

\section{Bibliography}

\section{Literature}

Brassey et al Competition Law

Brassey M et al Competition Law (Juta Cape Town 2002)

Chayes 1976 Harv L Rev

Chayes A "The Role of the Judge in Public Law Litigation" 1976 Harv L Rev 1281-1316

Connor and Lande "Cartel Overcharges"

Connor JM and Lande RH "Cartel Overcharges and Optimal Cartel Fines" in Collins WD (ed) Issues in Competition Law and Policy Volume 3 (American Bar Association Chicago, III 2008) 2203-2218

Gardner 2011 Law \& Phil

Gardner J "What is Tort for? Part 1 - The Place of Corrective Justice" 2011 Law \& Phil 1-50

Landes 1983 U Chi L Rev

Landes WM "Optimal Sanctions for Antitrust Violations" 1983 U Chi L Rev 652-678

Mbazira Litigating Socio-economic Rights

Mbazira C Litigating Socio-economic Rights in South Africa: A Choice between Corrective and Distributive Justice (PULP Pretoria 2009)

Modak-Truran 2000 Yale J L \& Human

Modak-Truran MC "Corrective Justice and the Revival of Judicial Virtue" 2000 Yale J L \& Human 249-298

Neethling, Potgieter and Visser Law of Delict

Neethling J, Potgieter JM and Visser PJ Law of Delict $7^{\text {th }}$ ed (LexisNexis Butterworths Durban 2015)

While the Supreme Court of Appeal in the Children's Resource Centre matter did not make a ruling on whether a claim for follow-on damages in terms of $s 65(6)$ of the Competition Act is to be classified as a statutory claim or a delictual claim, it is this author's opinion that based upon a proper interpretation of the relevant provisions of the Competition Act, together with the understanding that the common law is not to be amended unless the Legislature expressly does so (Fedlife Assurance Ltd $v$ Wolfaardt 2002 SA 49 SA (SCA)), damages actions arising from contraventions of the Competition Act must be dealt with as delictual actions. 
Neethling, Potgieter and Visser Neethling's Law of Personality

Neethling J, Potgieter JM and Visser PJ Neethling's Law of Personality $2^{\text {nd }}$ ed (LexisNexis Butterworths Durban 2005)

Niels, Jenkins and Kavanagh Economics for Competition Lawyers

Niels G, Jenkins $\mathrm{H}$ and Kavanagh J Economics for Competition Lawyers (Oxford University Press Oxford 2011)

Potgieter, Steynberg and Floyd Visser and Potgieter Law of Damages Potgieter JM, Steynberg L and Floyd TB Visser and Potgieter Law of Damages $3^{\text {rd }}$ ed (Juta Cape Town 2012)

Rawls Political Liberalism

Rawls J Political Liberalism (Columbia University Press New York 1993)

Roach Constitutional Remedies

Roach K Constitutional Remedies in Canada (Canada Law Book Toronto 1994)

Steyn Uitleg van Wette

Steyn LC Die Uitleg van Wette (Juta Cape Town 1981)

Sutherland and Kemp Competition Law

Sutherland P and Kemp K Competition Law of South Africa Service Issue 15 (LexisNexis Durban 2012)

Van den Heever Aquilian Damages

Van den Heever FP Aquilian Damages in South African Law (Juta Cape Town 1944)

Van der Walt and Midgley Principles of Delict

Van der Walt JC and Midgley JR Principles of Delict $3^{\text {rd }}$ ed (LexisNexis Butterworths Durban 2005)

Van Heerden and Neethling Unlawful Competition

Van Heerden HJO and Neethling J Unlawful Competition (LexisNexis Durban 2008)

Wellman "Justice"

Wellman CH "Justice" in Simon RL (ed) The Blackwell Guide to Social and Political Philosophy (Wiley-Blackwell Maiden, Mass 2002) 60-84

Wells and Eaton Constitutional Remedies

Wells M and Eaton TA Constitutional Remedies: A Reference Guide to the United States Constitution (Praeger Westport, Conn 2002) 


\section{Case law}

American Natural Soda Corporation v Competition Commissioner 20035 SA 633 (CAC)

Atlas Organic Fertilizers (Pty) Ltd v Pikkewyn Ghwano (Pty) Ltd 19812 SA $173(\mathrm{~T})$

Bastian Financial Services (Pty) Ltd v General Hendrik Schoeman Primary School 20085 SA 1 (SCA)

Bato Star Fishing (Pty) Ltd v Minister of Environmental Affairs 20044 SA 490 (CC)

Bester v Commercial Union Versekeringsmaatskapy van SA Bpk 19731 SA 769 (A)

Bredell v Pienaar 1924 CPD 203

Brenner v Botha 19563 SA 257 (T)

Cape of Good Hope Bank v Fischer (1886) 4 SC 368

Children's Resource Centre Trust v Pioneer Foods (Pty) Ltd; Mukaddam v Pioneer Foods (Pty) Ltd 2011 ZAWCHC 102 (7 April 2011)

Children's Resource Centre v Pioneer Food 20132 SA 213 (SCA)

Competition Commission of South Africa v Telkom SA Ltd 2010 All SA 433 (SCA)

Coronation Brick (Pty) Ltd v Strachan Construction Co (Pty) Ltd 19824 SA 371 (D)

Dadoo Ltd v Krugersdorp Municipal Council 1920 AD 530

Dun and Bradstreet (Pty) Ltd v SA Merchants Combined Credit Bureau (Cape) (Pty) Ltd 19681 SA 209 (C)

Elida Gibbs v Colgate Palmolive 19882 SA 350 (W)

Fedlife Assurance Ltd v Wolfaardt 2002 SA 49 SA (SCA)

Franschhoekse Wynkelder (Ko-op) Bpk v SAR \& H 19813 SA 36 (E)

Geary \& Son (Pty) Ltd v Gove 19641 SA 434 (A) 
Greenfield Engineering Works (Pty) Ltd v NKR Construction (Pty) Ltd 1978 4 SA $901(\mathrm{~N})$

Lascon Properties (Pty) Ltd v Wadeville Investment Co (Pty) Ltd 19984 SA $578(\mathrm{~W})$

Lillicrap, Wassenaar and Partners v Pilkington Brothers SA (Pty) Ltd 1985 1 SA 475 (A)

Link Estates (Pty) Ltd v Rink Estates (Pty) Ltd 19792 SA 697 (E)

Long John International v Stellenbosch Wine Trust 19904 SA 136 (D)

Lorimar Productions Incorporated v Sterling Clothing Manufacturers (Pty) Limited; Lorimar Productions Incorporated $v$ OK Hyperama Limited; Lorimar Productions Incorporated v Dallas Restaurant 19813 SA 1129 (T)

Matthews $v$ Young 1922 AD 492

Moaki v Reckitt and Colman (Africa) Ltd 19884 SA 63 (D)

Moroka Swallows Football Club v The Birds Football Club 19882 SA 350 (W)

Mukaddam v Pioneer Foods (Pty) Ltd 20132 SA 254 (SCA)

Mukaddam v Pioneer Foods (Pty) Ltd 20135 SA 89 (CC)

Nationwide Airlines (Pty) Ltd (in Liquidation) v South African Airways (Pty) Ltd 20166 SA 19 (GJ)

Olitzki Property Holdings v State Tender Board 20013 SA 1247 (SCA)

Perlman v Zoutendyk 1934 CPD 151

Pepsico Inc v United Tobacco Co Ltd 19882 SA 334 (W)

Phillips v National Director of Public Prosecutions 20061 SA 505 (CC)

Premier Foods (Pty) Ltd v Manoim 20161 SA 445 (SCA)

Prok Africa (Pty) Ltd v NTH (Pty) Ltd 19803 SA 687 (W)

Public Carriers Association v Toll Road Concessionaries (Pty) Ltd 19901 SA $925(A)$

SAD Holdings $v$ South African Raisins 20003 SA 766 (T)

Sage Holdings v Financial Mail 19912 SA 117 (W) 
Schultz v Butt 19863 SA 667 (A)

Sea Harvest Corporation v Irvin \& Johnson 19852 SA 355 (E)

Seagram Africa (Pty) Ltd v Stellenbosch Farmers' Winery 20012 SA 1129 (C)

Sibex Construction v Injectaseal 19882 SA 54 (T)

Silver Crystal Trading v Namibia Diamond Corporation 19834 SA 884 (D)

South African Raisins (Pty) Ltd v SAD Holdings Ltd 20012 SA 877 (SCA)

Standard Bank Investment Corporation Ltd v Competition Commission; Liberty Life Association of Africa Ltd v Competition Commission 20002 SA 797 (SCA)

Steenkamp v Provincial Tender Board, Eastern Cape 20063 SA 151 (SCA) Steenkamp v Provincial Tender Board, Eastern Cape 20073 SA 121 (CC)

Stellenbosch Wine Trust v Oude Meester Group 19723 SA 152 (C)

Stellenbosch Wine Trust v Oude Meester Group 19772 SA 221 (C)

Tie Rack plc v Tie Rack Stores 19894 SA 427 (T)

Times Media v SABC 19904 SA 604 (W)

Thoroughbred Breeders' Association v Price Waterhouse 20014 SA 551 (SCA)

Universiteit van Pretoria v Tommie Meyer Films (Edms) Bpk 19774 SA 376 (T)

University of Cape Town v Cape Bar Council 19864 SA 903 (A)

Victor Products (SA) (Pty) Ltd v Lataleure Manufacturing 19751 SA 961 (W)

WH Newson Holding Ltd v IMI PIc [2012] EWHC 3680 (Ch)

WH Newson Holding Ltd v IMI PIc [2013] EWCA Civ 1377

William Grant and Sons Ltd v Cape Wine Distillers Ltd 19903 SA 897 (C)

\section{Legislation}

Aviation Act 74 of 1962 
Compensation for Occupational Injuries and Diseases Act 130 of 1993

Competition Act 89 of 1998

Constitution of the Republic of South Africa, 1996

National Nuclear Regulator Act 47 of 1999

Post Office Act 44 of 1958

Prevention of Organised Crime Act 121 of 1998

\section{Internet sources}

European Commission 2013 http://europa.eu/rapid/press-release_IP-13525_en.htm

European Commission 2013 Press Release - Antitrust: Commission Proposes Legislation to Facilitate Damage Claims by Victims of Antitrust Violations http://europa.eu/rapid/press-release_IP-13-525_en.htm accessed 21 January 2018

Lianos 2011 https://www.ucl.ac.uk/drupal/cles/sites/cles/files/cles_3_ 2011new.pdf

Lianos I 2011 Competition Law Remedies: In Search of a Theory https://www.ucl.ac.uk/drupal/cles/sites/cles/files/cles_3_2011new.pdf accessed 21 January 2018

Scallan, Mbikiwa and Blignaut 2013 http://www.compcom.co.za/wpcontent/uploads/2014/09/Conference-Paper-Final-21-08-2013.pdf

Scallan A, Mbikiwa M and Blignaut L 2013 "Compensating for Harm Arising from Anti-competitive Conduct" Paper delivered at the Seventh Annual Competition Law Economics and Policy Conference (5-6 September 2013 Sandton) http://www.compcom.co.za/wp-content/uploads/2014/09/ Conference-Paper-Final-21-08-2013.pdf accessed 21 January 2018

Vallentyne Date Unknown http://klinechair.missouri.edu/docs/ distributive_justice_handbook.pdf

Vallentyne $\mathrm{P}$ Date Unknown Distributive Justice http://klinechair.missouri.edu/docs/distributive_justice_handbook.pdf accessed 21 January 2018

\section{LIST OF ABBREVIATIONS}

Harv L Rev

Law \& Phil

U Chi L Rev

Yale J L \& Human
Harvard Law Review

Law and Philosophy

University of Chicago Law Review

Yale Journal of Law and the Humanities 